\title{
KULTURA PRZEWORSKA W REJONIE ŚRODKOWEJ I DOLNEJ BZURY. STUDIUM Z DZIEJÓW OSADNICTWA
}

(autoreferat wygłoszony w trakcie obrony pracy doktorskiej w dniu 12 lipca 2004 r.)

Do przeprowadzenia niniejszych studiów wybrano mikroregion osadniczy obejmujący obszar położony w zlewisku Bzury pomiędzy jej prawobrzeżnymi dopływami Uchanką a Utratą oraz lewobrzeżnymi Nidą i Witonią. Osią obszaru jest dolina Bzury. Zasięg terenu na północ i południe wytyczyły mapy osadnictwa (ryc. 1) 1 . Wybór taki uzasadnia obecność na tym obszarze wyraźnie odrębnych stref zasiedlenia. Wielkość badanego obszaru przekracza nieco $2000 \mathrm{~km}^{2}$. Rzeźbę terenu stanowią głównie formy czwartorzędowe pochodzenia lodowcowego i eolicznego. Cechami wybijającymi się i ważnymi dla osadnictwa są silnie rozbudowana sieć dolin rzecznych oraz wydmy występujące na terasach Bzury i jej głównych dopływów.

Pomimo że zainteresowania przeszłością pradziejową badanego regionu datują się już od końca XIX stulecia, to nie doczekał się on jak dotychczas bardziej szczegółowych opracowań monograficznych. Dość przypadkową specyfiką omawianego rejonu jest więcej zbadanych i opublikowanych osad niż cmentarzysk, co daje stosunek odwrotnie proporcjonalny do innych badanych regionów kultury przeworskiej. W sumie znamy 5 rozpoznanych w różnym stopniu osiedli, z których 3 są przynajmniej częściowo opublikowane (Antoniew, stan. 1, Różyce Stara Wieś, stan. 3+1 i stan. 8, Wólka Łasiecka, stan. 2 oraz Sochaczew, stan. 10), a tylko 2 cmentarzyska w Woli Szydłowieckiej, stan. 1, i Żdżarowie, stan. 1, z którego wyniki badań opublikowano w całości. Kilka pozostałych cmentarzysk to stanowiska zniszczone lub takie, które były publikowane jedynie wyrywkowo lub wcale (np. Kęszyce, stan. 1, Kuznocin, stan. 1, Sierzchów, stan.1, Kocierzew, stan. 3, Wólka Łasiecka, stan. 1, Sochaczew-Trojanów, Kompina, stan. 12). Pozostałe to znaleziska pojedyncze, nieraz bardzo znaczące, oraz pochodzące $\mathrm{z}$ badań Archeologicznego Zdjęcia Polski, o różnej wartości poznawczej. Na tym terenie od wielu lat prowadzi również badania autor przedstawianej pracy.

Szczególnie istotne dla dalszych rozważań podjętego tematu było sprecyzowanie znaczenia podstawowych pojęć, a w szczególności terminów os a dn i ctwo i stre fa zas i ed l e n i a. Zasadniczą cechą przyjmowanych sformułowań jest położenie nacisku na ingerencję społeczności ludzkich w środowisko naturalne i na dynamikę takich działań. Precyzując

\footnotetext{
'Oznaczone ramkami na mapie $\mathrm{nr} 1$, szczegółowe mapy skupisk osadniczych nie zostały uwzględnione w niniejszej publikacji.
} 


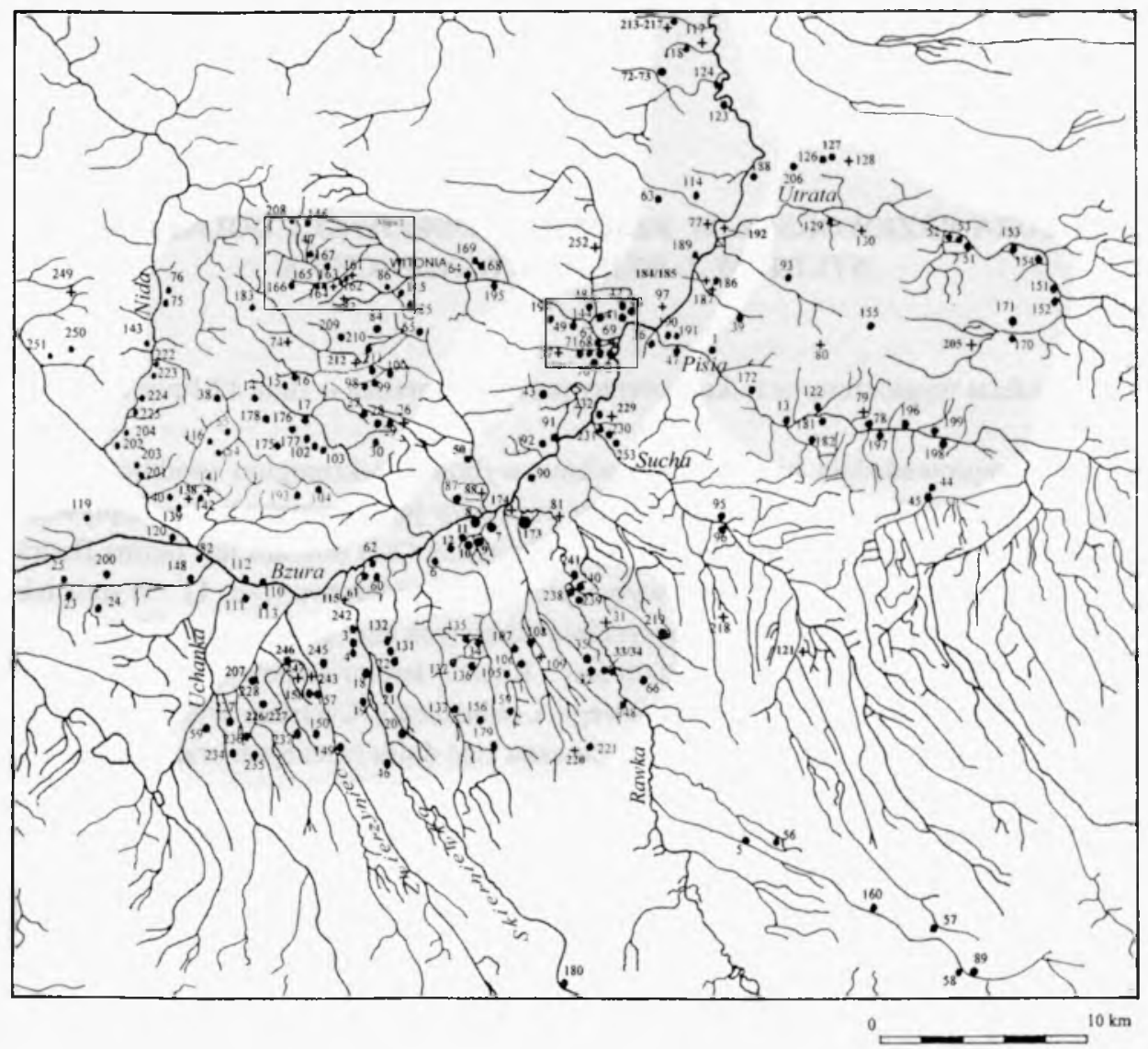

Ryc. 1. Osadnictwo kultury przeworskiej nad środkową i dolną Bzurą - obraz skumulowany ze wszystkich okresów chronologicznych: • osady, ślady osadnictwa i punkty osadnicze, strefy zasiedlenia, + cmentarzyska

własną definicję, oparłem się głównie na ujęciu problemu przez S. Kurnatowskiego i J. Żaka. Wychodząc z założenia, że wszelkie ludzkie działania odbywają się w określonym czasie, przyjąłem, że „osadnictwo to każda forma zorganizowanej, trwałej ingerencji określonej spoleczności w środowisko, w której czynnik przestrzeni jako takiej leży u podstaw wszystkich podejmowanych decyzji". Przy czym w pojęciu p r z e s t r z e n i mieści się także kultura duchowa (przestrzeń metafizyczna), która znajduje częściowe odzwierciedlenie w świecie materialnym. Natomiast ,strefa zasiedlenia to wszelki przejaw działalności człowieka tak pojedynczego, jak i grup - wynikający z jego, lub ich, mobilności w przestrzeni".

Chronologię oparłem na ogólnie przyjętej systematyce okresu przedrzymskiego i rzymskiego zaproponowanej przez K. Godłowskiego (1970), T. Li an ę (1970) i T. Dą browską (1988), z późniejszymi modyfikacjami. 


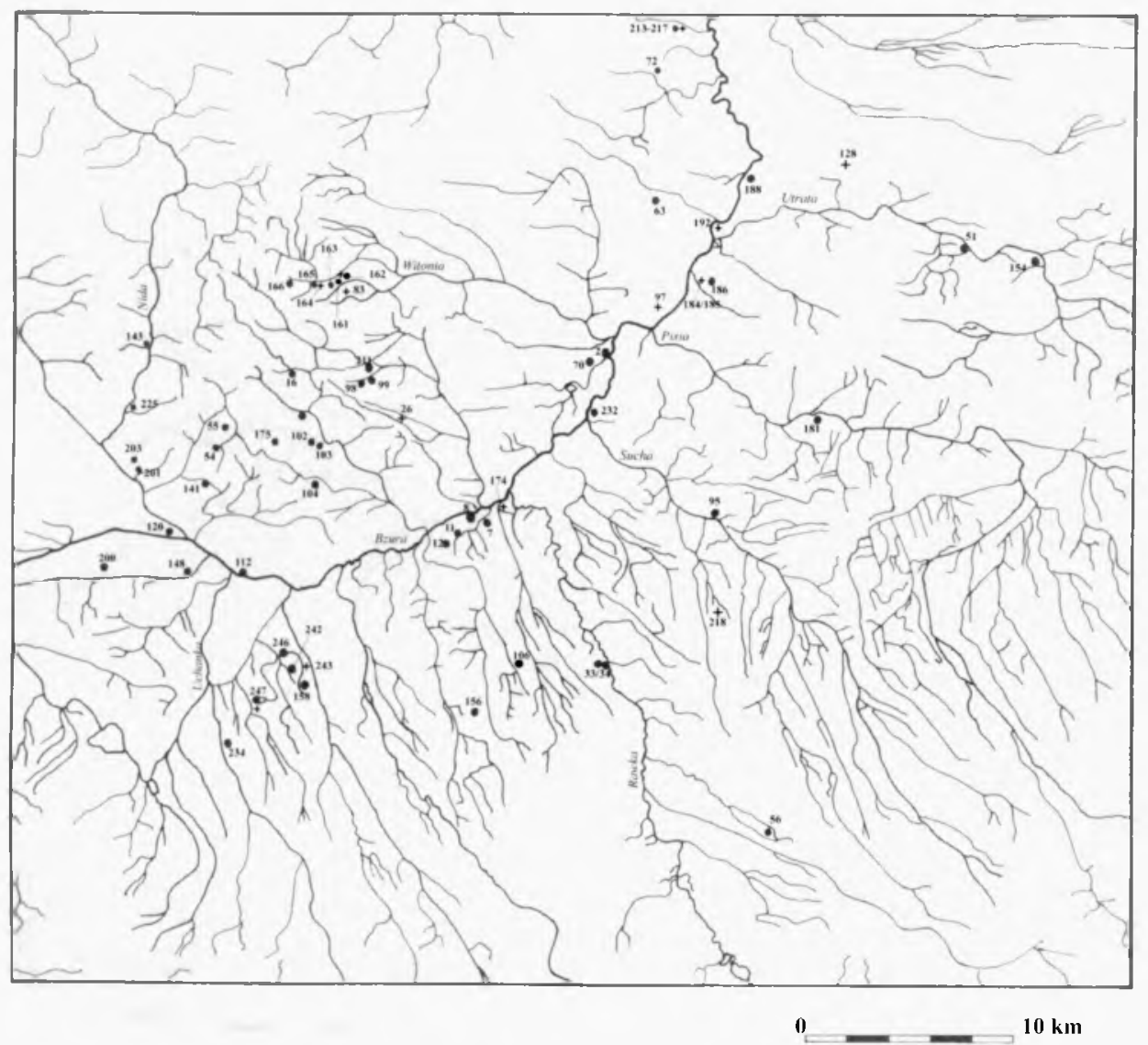

Ryc. 2. Osadnictwo kultury przeworskiej w młodszym okresie lateńskim i początkach starszego okresu rzymskiego: - osady, ślady osadnictwa i punkty osadnicze, + cmentarzyska

$\mathrm{Na}$ badanym obszarze zaznaczają się wyraźnie cztery odrębne strefy zasiedlenia. Oznaczyłem je według nazw głównych rzek, pomiędzy którymi lub wzdłuż których się rozlokowały (ryc. I - zaznaczone szarą barwą). Na północ od doliny Bzury osadnictwo grupuje się między Nidą a Witonią. Sama dolina Bzury stanowi oś, wzdłuż której rozlokowała się kolejna sieć skartowanych punktów osadniczych. Większość z nich rozłożona jest od południowej strony doliny rzeki. Kolejna strefa zasiedlenia występuje między prawobrzeżnymi dopływami Bzury - Uchanką a Rawką. Ostatnia, dość słabo wydzielająca się strefa, zajmuje tereny od doliny Pisi po Utratę. Pas między dolinami Rawki i Pisi nie wykazuje większych koncentracji osadnictwa. Pomiędzy wszystkimi wymienionymi strefami zasiedlenia widoczne są pasy pustek nazwanych anekumenami.

W obrębie każdej z wymienionych stref zasiedlenia można wyróżnić po kilka wyodrębniających się skupisk osadniczych. Niestety, trudno określić szczegółową chronologię 


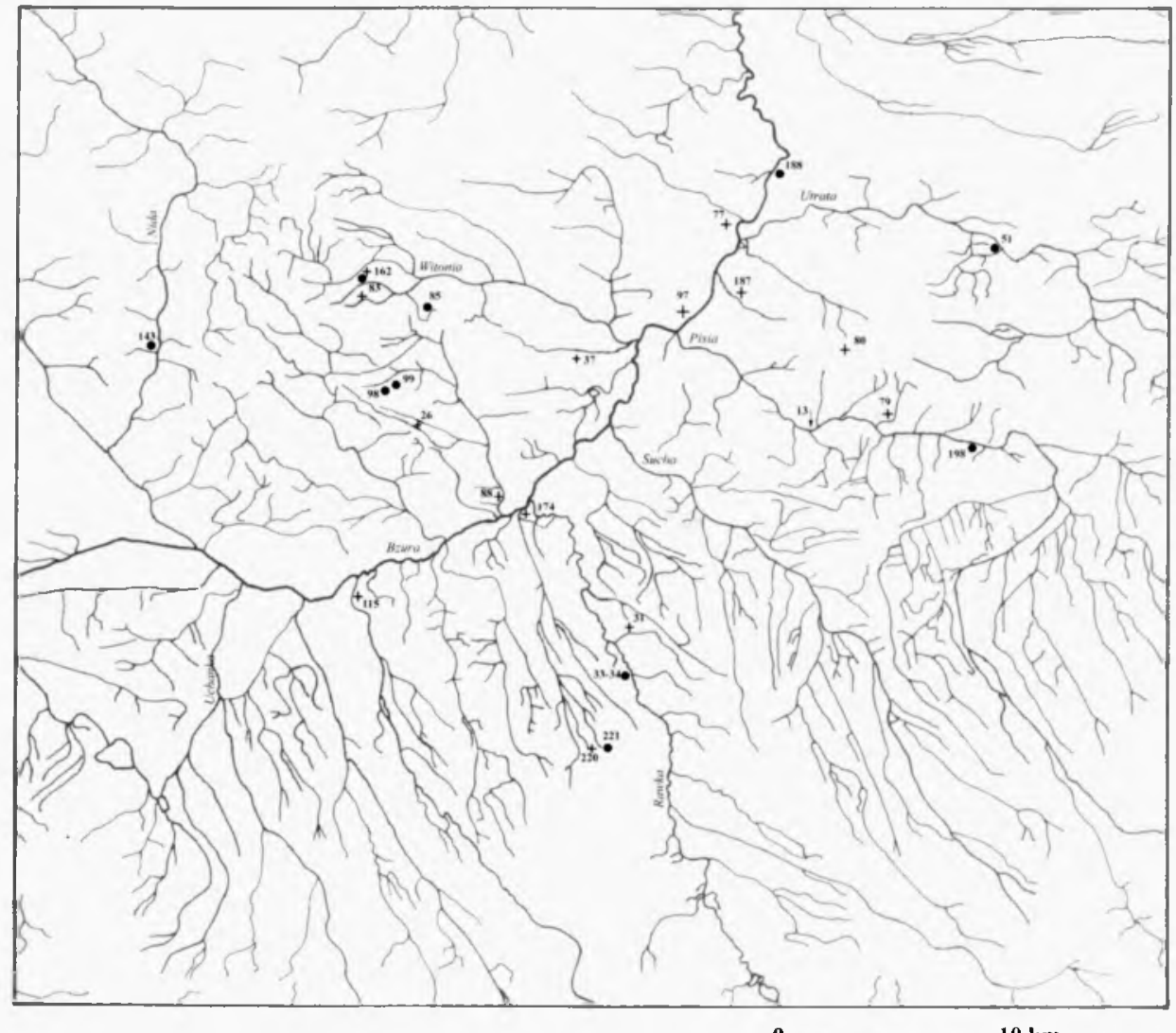

0

$10 \mathrm{~km}$

Ryc. 3. Osadnictwo kultury przeworskiej w starszym okresie rzymskim: • osady, ślady osadnictwa i punkty osadnicze, + cmentarzyska, $\downarrow$ znaleziska bagienne

ich rozwoju. Mapa zbiorcza pokazuje skumulowany obraz osadnictwa od razu dla całego okresu istnienia kultury przeworskiej (ryc. 1). Szczegółowe mapy chronologiczne poszczególnych podokresów obrazująjedynie obecny stan badań (ryc. 2-4). Porównując je z mapą kumulacyjną (ryc. 1), widać, że nie mogą być one wyłączną podstawą do szczegółowej analizy przemian osadnictwa. Jednym $z$ dowodów jest istnienie odizolowanych osad bez powiązanych z nimi cmentarzysk lub cmentarzysk ulokowanych samotnie, do których nie można przyporządkować osad.

Dyslokacja skumulowanego obrazu osadnictwa pozwala jednak na wysunięcie tezy, że wyróżnione strefy zasiedlenia nie są przypadkowe. Wiąże się z tym kwestia wyraźnych obszarów pustek osadniczych, nazwanych przez nas anekumenami. Ich szerokość wynosi średnio około 3,5-4 km. W obrębie tych pasów pustek nie zarejestrowano dotychczas żadnych śladów penetracji ludzkiej. Być może wynika to częściowo ze stanu badań. Istnienie rozległych pustek osadniczych pomiędzy różnymi plemionami europejskiego 


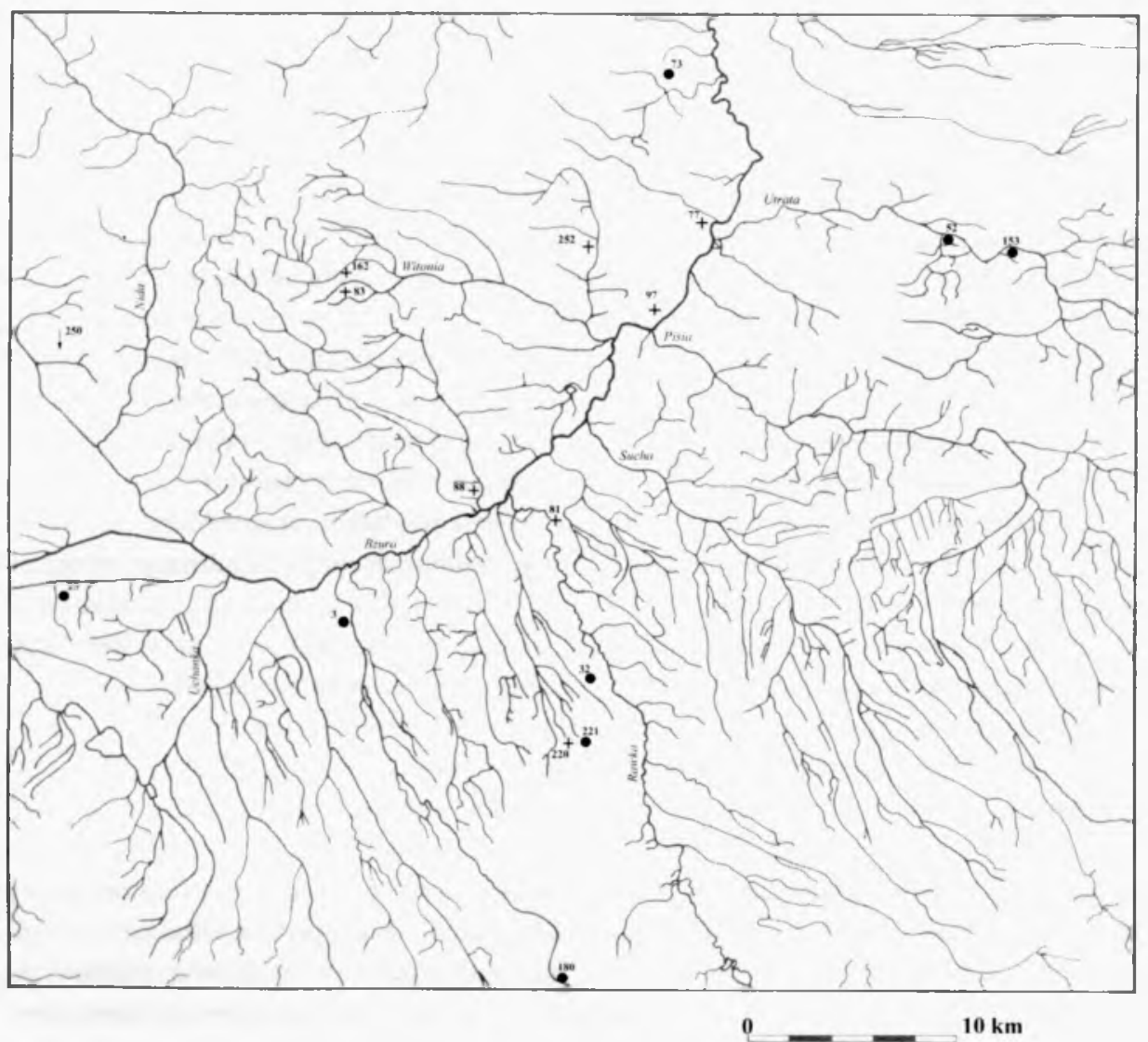

Ryc. 4. Osadnictwo kultury przeworskiej w młodszym okresie rzymskim i okresie wędrówek ludów: • osady, ślady osadnictwa i punkty osadnicze, + cmentarzyska, $\downarrow$ znaleziska bagienne

Barbaricum poświadcza relacja Cezara (Commentari de bello gallico). W obrębie każdej strefy występują tereny o większej lub mniejszej okupacji, a czasowo sporadycznie penetrowane przez osadników. Analiza skartowanych stref zasiedlenia, pozwala dopatrywać się w nich pewnych odrębnych jednostek, prawdopodobnie o charakterze społeczno-ekonomicznym. Można przypuszczać, że poszczególne strefy trwały przez cały okres istnienia kultury przeworskiej, co dokumentują mapy chronologiczne. Każda z wyróżnionych przeze mnie czterech jednostek, mogłaby w istocie stanowić wspólnotę opartą na zrzeszeniu rodzin. Można więc wysunąc hipotezę o tożsamości strefy zasiedlenia ze wspólnotą rodowa.

Najmniejszą jednostką w obrębie dużych wspólnot była zawsze poszczególna osada, a w jej obrębie dom mieszkalny $i$ towarzyszące mu gospodarstwo. Osady z badanego terytorium można generalnie podzielić na osady duże, czyli stałe, oraz małe, w skład których wchodzą osiedla sezonowe i obozowiska. Wśród osad stałych znalazło się $5 \mathrm{w}$ różnym 
stopniu rozpoznanych osiedli. Są to osady w Wólce Łasieckiej stan. 2, Różycach Starej Wsi stan. $3+1$ i stan. 8, Antoniewie stan. 1 i Sochaczewie stan. 10. Przedstawione wyżej osiedla reprezentują dwie odrębne grupy chronologiczne. Osada w Antoniewie stan. 1, i I faza zabudowy w Różycach Starej Wsi stan. 3+1, oraz osada na stanowisku 8, pochodzą z młodszego okresu przedrzymskiego i początków starszego okresu rzymskiego. Druga faza osiedla różyckiego, rozpoznany fragment osady w Sochaczewie stan. 10 i osada w Wólce Łasieckiej odpowiadają starszemu i młodszemu okresowi rzymskiemu.

W przypadku osad pierwszej grupy chronologicznej widoczna jest przede wszystkim ścisłość zabudowy oraz jej wyraźnie wspólnotowy charakter. Brak tam przesłanek do wydzielenia poszczególnych gospodarstw czy zagród. Prawdopodobnie w obu osiedlach istniały place wewnętrzne przeznaczone dla zebrań czy innych działań podejmowanych na rzecz całej społeczności. Także niektóre obiekty gospodarcze mogły być użytkowane wspólnie. Obserwacje te mogą wspierać pogląd o zakorzenionej wówczas wspólnocie, gdzie mniejsze znaczenie miała gospodarcza indywidualizacja poszczególnych rodzin.

Osady drugiej grupy chronologicznej są bardziej zróżnicowane. Na przykład druga faza osiedla z Różyc Starej Wsi stan. 3+1 wykazuje mniejszą ścisłość zabudowy. Osiedle w Wólce Łasieckiej ma natomiast wyraźny podział na strefy o zabudowie mieszkalno-gospodarczej, gospodarczej i prawdopodobnie o przeznaczeniu społecznym (budowla halowa + zespół palenisk). Osobno należy rozpatrywać wielkoizbowy dom nr $10 \mathrm{wraz}$ z otoczeniem, należący zapewne do bogatszych przedstawicieli społeczności. Uogólniając, należałoby przypuszczać, że zabudowa osiedli rejonu środkowej i dolnej Bzury w okresie rzymskim, a szczególnie w jego późniejszych fazach, przekształca się w skupiskowa, zmierzając być może do większej indywidualizacji gospodarstw rodzinnych.

Budownictwo w osadach stałych można podzielić ogólnie na naziemne i częściowo zagłębione w ziemię. Pod względem powierzchni i rozplanowania wewnętrznego budynków naziemnych wyróżniają się standardowe domy mieszkalne, budowle halowe i domy wielkoizbowe. Osobną kategorię stanowią też mniejsze, naziemne budynki gospodarcze. Powierzchnie budynków z badanego terytorium można opisać, generalizując je do trzech podstawowych kategorii. Są to budowle o powierzchni do około $10 \mathrm{~m}^{2}$, do około $30 \mathrm{~m}^{2}$ i znacznie powyżej $30 \mathrm{~m}^{2}$. Ogółem z badanego terytorium znamy 34 budynki naziemne. Posiadają one $z$ reguły kształt zbliżony do prostokąta, a w niektórych można zaobserwować podział wewnętrzny na izbę, sień a nawet podcień (Różyce Stara Wieś stan. 3+1, Wólka Łasiecka stan. 2, Antoniew stan. 1).

Najpowszechniejszą techniką wznoszenia ścian była konstrukcja słupowa. Na takim szkielecie można było oprzeć ścianę plecionkową lub sumikowo-łątkowa. Jednoznaczna interpretacja większości śladów trafia na trudności. Dodatkowo komplikuje zagadnienie możliwość łączenia obu technik. W Antoniewie z 6 zbadanych dotychczas budowli naziemnych 2 można z pewnymi zastrzeżeniami określić jako sumikowo-łątkowe. Jedną (dom nr 2) wzniesiono w technice mieszanej, przy czym plecionkowa była wewnętrzna ścianka działowa. Jedyny budynek wzniesiony prawdopodobnie w konstrukcji zrębowej pochodzi z osady ze starszego okresu rzymskiego w Sochaczewie stan. 10. Do wyjątkowych 
znalezisk związanych $\mathrm{z}$ budową ścian należą bryłki otynkowanej polepy z budynku $\mathrm{nr} 2$ w Antoniewie i niedawno odkrytego, jedynego budynku z osady w Bolimowie stan. $4+5$. Posiadane materiały nie upoważniają nas do wnioskowania o istnieniu określonej tradycji lokalizacji wejść. Z rozplanowania osiedli wynika jednak, że starano się umieszczać je w zgodzie z ogólną koncepcją przestrzenną zabudowy - w stronę dróg wewnętrznych (Różyce Stara Wieś stan. 3+1 - faza II) lub placu (Antoniew). Dachy prawdopodobnie dwuspadowe, rzadziej jednospadowe, były oparte na konstrukcji słupowej w technice na sochy szczytowe lub. być może, slegowej. We wnętrzu budynku mieszkalnego znajdowało się najczęściej brukowane kamieniami palenisko, rzadziej niewielki kopułkowy piec (Antoniew).

Osobną kategorią budowli naziemnych, które mogły służyć jako mieszkalne, są budynki halowe i wielkoizbowe. Ich powierzchnia przekracza znacznie $100 \mathrm{~m}^{2}$. Znamy je $\mathrm{z}$ omawianego obszaru jedynie z osady w Wólce Łasieckiej. Budynki tego typu wydają się nietypowe dla tradycji budowlanych kultury przeworskiej. Budownictwo tego rodzaju wykazuje związki z północnonadłabskim lub południowoskandynawskim kręgiem kulturowym.

Obok budowli mieszkalnych egzystowały także w osiedlach naziemne budowle gospodarcze. $Z$ badanego obszaru znanych jest kilka takich budowli. Jednym $z$ ciekawszych jest budynek 11 z Różyc Starej Wsi interpretowany jako kuźnia. Pozostałe mogły pełnić różne funkcje - od magazynów i spichrzów po miejsca wyspecjalizowanej produkcji.

Ważnym elementem krajobrazu osadniczego są tereny z rozmysłem przeznaczane do wykorzystywania sezonowego lub na pobyty organizowane na krótko, a często zapewne przypadkowo, w trakcie realizacji różnego rodzaju przedsięwzięć. Są one istotną składową stre fy z a si ed l e n i a, manifestując się najczęściej w postaci znalezisk luźnych czy punktów osadniczych bądź osad, na których brak stałej zabudowy naziemnej. Na podstawie skartowanych skupisk osadniczych można domniemywać, że osiedla sezonowe wiązały się przede wszystkim z określoną produkcją gospodarczą, pasterstwem lub trzebieżą lasów. Bliskość mazowieckiego ośrodka hutniczego (około $25-35 \mathrm{~km}$ w prostej linii) narzuca pewne wnioski dotyczące rozlokowania osadnictwa w okresie intensywnego użytkowania piecowisk na przełomie er. Prawdopodobnie strefy zasiedlenia pomiędzy Bzurą a Rawką i Utratą mogły stanowić część stałego zaplecza osadniczego, którego mieszkańcy zakładali osady sezonowe w pobliżu miejsc wytopu żelaza. Można przypuszczać, że jedną z nich jest osada z I fazy zasiedlenia (od schyłku fazy $A_{1}$ młodszego okresu przedrzymskiego do przełomu er) w Izdebnie Kościelnym stan. 1, gm. Grodzisk Mazowiecki. Obecność materiałów pochodzenia jastorfskiego wiąże ją z osadą w Antoniewie stan. 1, której chronologia jest zbliżona.

Podstawą utrzymania ludności kultury przeworskiej w rejonie środkowej i dolnej Bzury była gospodarka rolniczo-hodowlana. Odciski słomy zbóż są widoczne w wielu grudach polepy ze wszystkich badanych osad. Na fragmentach naczyń w osiedlu różyckim odkryto odciski ziaren kaszy, prawdopodobnie jaglanej. Z kolei pozostałości ziaren żyta zaobserwowano na zewnętrznej powierzchni dna jednego z naczyń z osady w Wólce 
Łasieckiej. Spośród znalezisk narzędzi rolniczych, dokonywanych na osadach w omawianym rejonie, należy wymienić lekko łukowaty sierp żelazny, znaleziska rozcieraczy kamiennych, połupanych żaren nieckowatych oraz fragmenty żaren rotacyjnych. $Z$ badań archeozoologicznych kości zwierzęcych znajdywanych w osadach wynika, że hodowla bydła znacznie przeważała nad hodowlą trzody chlewnej. Znany był koń i pies. Pozostałe to szczątki zwierząt dzikich, głównie sarny, jelenia i dzika. W zbadanym zbiorze $78 \%$ stanowią szczątki zwierząt hodowlanych, a $12 \%$ zwierzyny łownej. Ważne miejsce w gospodarce odgrywała obróbka gliny i produkcja naczyń. Znane są resztki pieców garncarskich i liczne półprodukty lub odpady produkcyjne naczyń glinianych. Wyjątkowe jest znalezisko pieca do kruszenia kamieni, stosowanych później jako domieszka schudzająca masy ceramicznej (Antoniew). Niemałe znaczenie miała obróbka żelaza, głównie o charakterze przydomowym, na własne potrzeby. Ślady wapiennictwa zaobserwowano m.in. w postaci użytkowania wapna do tynkowania ścian domostw oraz pokrywania nim powierzchni niektórych naczyń. O popularności tkactwa świadczą liczne znaleziska ciężarków tkackich i przęślików. Znane są przypadki obróbki kamienia, kości i rogu. Dużą rolę musiała odgrywać ciesiołka. Także handel był bardzo istotną częścią życia gospodarczego. Najpewniejszej wiedzy o dalekosiężnych kontaktach handlowych dostarczają niewątpliwie ,importy” przedmiotów luksusowych oraz monety. Znamy liczne znaleziska paciorków szklanych, ułamki naczyń terra sigillata, fragmenty naczyń brązowych oraz monety rzymskie odkrywane zarówno w postaci skarbów, jak i pojedynczych znalezisk. Największa liczba znajdowanych monet pochodzi z czasów Antoninów.

Charakterystyka kultury materialnej ludności kultury przeworskiej w rejonie środkowej i dolnej Bzury jest zdeterminowana rodzajem posiadanych źródeł, w których przeważają znaleziska $z$ osad. Ogółem z tego obszaru znamy 51 zapinek. Przeważają fibule o konstrukcji późnolateńskiej odmiany M-N według J. Kostrzewskiego oraz różne wersje zapinek silnie profilowanych IV grupy $\mathrm{O}$. Almgrena, w których dominują fibule odmiany mazowieckiej typu 1A i IB, według T. Dąbrowskiej, charakterystyczne od fazy B2b po fazę $\mathrm{Cl}$ okresu rzymskiego. Interesujące, na tle ogółu znalezisk, są dwie brązowe, inkrustowane srebrem zapinki typu AIV,71 z Sochaczewa, które na terenie kultury przeworskiej występują bardzo rzadko i wywodzą się z obszaru Jutlandii i północno-wschodnich Niemiec. Podobne koneksje posiada zapinka AV,115-119 znaleziona w Wólce Łasieckiej. Pozostałe grupy reprezentowane są nielicznie, choć obrazują prawie pełny cykl chronologiczny kultury przeworskiej. Wśród elementów stroju znajdują się szpile nawiązujące do tradycji wielbarsko-baltyjskich. Na zestaw uzbrojenia składają się znaleziska mieczów obosiecznych i jednosiecznych, fragmenty pochew, licznych grotów broni drzewcowej, elementów tarcz oraz ostrogi. Na uwagę zasługują fragmenty rzędu końskiego typu Vimose o genezie celtycko-rzymskiej, znalezione w Zlakowie Kościelnym. Największą grupę znalezisk stanowią oczywiście naczynia gliniane lub ich fragmenty, zarówno lepione ręcznie, jak i wykonywane na kole garncarskim. Dla naczyń ręcznie lepionych skonstruowałem własną typologię, nie rozdzielając z góry materiału na ceramikę późnolateńską i z okresu rzymskiego. 
Odrębnym zagadnieniem są uchwytne archeologicznie elementy kultury duchowej. Można je podzielić na trzy rodzaje znalezisk: odkrycia na osadach, znaleziska bagienne oraz cmentarzyska. W obrębie osiedli z okresu przedrzymskiego znajdowane były depozyty ofiarne w postaci pochówków psów, rzadziej innych zwierząt (np. kozy), lokowane najczęściej w pobliżu domów lub wręcz pod ich ścianami. Znane są także depozyty w postaci fragmentów czaszek ludzkich umieszczane w bezpośredniej bliskości ścian domostw (Różyce Stara Wieś stan. 3+1 i stan. 8). Stanowiły one zapewne pozostałości różnorakich zabiegów magicznych, od zabezpieczenia ogniska domowego (psy) po elementy obrzędów agrarnych (szczątki ludzkie) o bardzo starej metryce. Zupełnym ewenementem jest znalezisko miejsca ofiarnego na osadzie w Antoniewie, którego konstrukcja w kształcie podkowy, jak i symbolika, nie mają - jak dotychczas - odpowiedników na obszarze kultury przeworskiej i terenach sąsiednich. Najbliższe analogie konstrukcyjne znajdujemy w Dolnej Saksonii. Z obrzędami ofiarnymi łączą się także znaleziska bagienne znane z kilku miejscowości. Z kolei na cmentarzyskach obserwujemy inne elementy zjawisk związanych z kulturą duchową. Dotyczą one głównie form pochówków. Specyfiką badanego terenu jest występowanie na cmentarzyskach różnorodnych konstrukcji kamiennych: stel, kręgów, bruków oraz ogrodzeń kamiennych, obcych tradycji kultury przeworskiej. Jest to widoczne na przykład na cmentarzyskach w Kęszycach, Sierzchowie czy Kocierzewie Południowym i Kompinie. Jak się wydaje, mogą się one wiązać $\mathrm{z}$ kontaktami ludności badanego obszaru z kręgiem północnonadłabskim oraz południowoskandynawskim, jakie występowały już od okresu późnolateńskiego. W okresie rzymskim należy się liczyć z powiązaniami i oddziaływaniem kultury wielbarskiej.

Rozważając cechy odrębności kultury przeworskiej w rejonie środkowej i dolnej Bzury od pozostałej części zajmowanego przez nią obszaru, należy właśnie zwrócić uwagę na jej związki z innymi zespołami kulturowymi. Wobec braku bezpośrednich danych trudno określić, czy zetknięcie się z wcześniejszym chronologicznie zespołem kulturowym pomorsko-kloszowym w ogóle występowało, a jeżeli tak, to czy w jakiś sposób oddziałało na kształtowanie się kultury przeworskiej. Pewne ślady, jak użytkowanie tych samych cmentarzysk (Sochaczew-Trojanów, Wola Szydłowiecka), bez widocznego konfliktu stratygraficznego, mogą świadczyć o czasowej koegzystencji obu społeczności. Obecny stan wiedzy pozwala jedynie na czysto teoretyczne spekulacje. Inaczej wyglądają relikty powiązań $\mathrm{z}$ innymi kręgami kulturowymi: celtyckim, nadłabskim i jutlandzkim oraz poludniowo-skandynawskim. Niektóre fakty, takie jak próby malowania widoczne na naczyniach lepionych ręcznie i ułamki późnolateńskich naczyń toczonych, a być może też pochodzenie pewnych obyczajów ofiarnych można wiązać ze strefą oddziaływań celtyckich, może z terenów południowej Polski lub Kujaw. Lepiej czytelne są pozostałości powiązań nadłabskich i jutlandzkich, kojarzone $\mathrm{z}$ kulturą jastorfską. Znajdujemy je w formach naczyń glinianych, na przykład w postaci ukształtowania strefy wylewu czy występowaniu specyficznych krążków ceramicznych. Zarówno celtyckie, jak i jastorfskie elementy kulturowe widoczne są w materiałach późnolateńskich. Wiążą się one zapewne z procesami latenizacji i formowaniem się kultury przeworskiej. Badany obszar znajdował się wówczas prawdopodobnie na szlaku wędrówek celto-germańskich Skirów i Bastarnów. Późniejsze 
kontakty z obszarami południowoskandynawskimi i północnoniemieckimi zachodziły już w okresie rzymskim i zależały od impulsów promieniujących poprzez tereny zamieszkałe przez ludność kultury wielbarskiej. Są one widoczne m.in. w konstrukcjach kamiennych na cmentarzyskach, obecności dużych domów w osadach czy niektórych zabytkach ruchomych, jak wspominane wyżej zapinki A71 czy Al15-119.

$\mathrm{Z}$ dotychczasowych badań podejmowanych w rejonie środkowej i dolnej Bzury wynika, że obszar ten znajdował się w okresie późnolateńskim w strefie przenikania pewnych zjawisk kulturowych na linii północny zachód - południowy wschód. Dużą rolę w tych wydarzeniach odgrywały zapewne oddziaływania płynące z pobliskich Kujaw. Osadnictwo kultury przeworskiej w tym czasie, a także w starszym okresie rzymskim, odczytujemy jako już silnie rozbudowane i wykazujące tendencje rozwojowe. Ślady kontynuacji zasiedlania omawianego rejonu znajdujemy przez cały okres rzymski. Należą do nich dobrze rozpoznane pod względem chronologicznym stanowiska w Różycach Starej Wsi z II fazy osadniczej, Kocierzewie Południowym, Kompinie, Wólce Łasieckiej, Żdżarowie lub Karwowie. Okres schyłkowy - zaniku kultury przeworskiej - znany jest najsłabiej, co jest przede wszystkim wynikiem stanu badań. Chociaż, jak można sądzić na podstawie nielicznych znalezisk $z$ terenów sąsiednich, może to też być skutkiem pewnych przemian kulturowych trudno uchwytnych archeologicznie. Niektóre fakty, na przykład pewne naczynia wykonywane na kole czy okazy zapinek i paciorków lub złota lunula ze Skierniewic-Ławek oraz chronologia cmentarzyska w Żdżarowie pozwalają dość jednoznacznie odnieść je do fazy $\mathrm{C}_{2}-\mathrm{D}_{1}$ młodszego okresu rzymskiego (druga połowa IIl do początku $V$ w.n.e.) jako na pewno reprezentowanej w materiale kultury przeworskiej w rejonie środkowej i dolnej Bzury. Z samego schyłku okresu rzymskiego i początków okresu wędrówek ludów brak jak dotychczas wystarczającej ilości jednoznacznych znalezisk. Bez powiększenia w tym zakresie bazy źródłowej nie można wysnuwać wniosków dotyczących zaniku kultury przeworskiej w omawianym rejonie.

Na zakończenie trzeba powrócić do pewnych obserwacji ogólnych związanych z rozwojem gospodarczym i wynikającą z niej, jak się wydaje, spójnością terytorialną osadnictwa na poziomie regionalnym, a nawet ponadregionalnym. Egzystujący nieopodal mazowiecki ośrodek hutnictwa żelaza trwał od I w. p.n.e. po IV w. n.e. Pomimo znacznego postępu prac terenowych, a z powodu braku opracowań, wiemy o nim niewiele. Można jednak bez większego ryzyka przypuszczać, że odgrywał on olbrzymią rolę dla społeczności zamieszkujących pobliskie strefy zasiedlenia. Przedsięwzięcie na tak wielką skalę w wymiarze przestrzennym i czasowym świadczy o silnych, a także stabilnych podstawach organizacyjnych. Wydaje się, że strukturalnie mogło mieć ono wymiar plemienny. Zanik tak długo trwającego i intratnego ekonomicznie ośrodka nie mógł być pozbawiony przyczyn. Sądzę, że dalsze, kompleksowe badania dotyczące poszczególnych stref zasiedlenia całego regionu zachodniego Mazowsza stanowią istotne wyzwanie dla archeologii. 